\title{
Upper Cretaceous Benthic Foraminifera Thriving in Intertidal Areas of the Apennine Carbonate Platform
}

\section{Consorti L* \\ Department of Mathematics and Geosciences, University of Trieste, Italy}

*Corresponding author: Consorti L, Department of Mathematics and Geosciences, University of Trieste, Via Weiss 2, Trieste, Italy, Email: lorenzo.consorti.es@gmail.com; lconsorti@units.it

\section{Research Article}

Volume 3 Issue 1

Received Date: October 06, 2020

Published Date: November 04, 2020

\section{Abstract}

The intertidal area of carbonate platform hosts a complex array of ecological networks in which microbials, algae, cyanobacteria and benthic foraminifera coexist. Being influenced by the amplitude of tides, intertidal areas frequently experience episodes of extreme conditions, including hypersaline waters and elevate daily temperatures. An interesting record of Upper Cretaceous fossil benthic foraminifera found within the intertidal facies of Apennine Carbonate Platform is presented and discussed. Two local gatherings of juvenile Scandonea and adult Rotalispira maxima suggest that the intertidal area was frequently colonized by benthic foraminifera. The results show that these populations of foraminifera were able to tolerate periods of extreme salinity and temperature for reproduction or feeding purposes.

Keywords: Upper Cretaceous; Apennines; Foraminifera; Intertidal Area

\section{Introduction}

The intertidal area is defined as a peri-coastal zone influenced by tides and classically situated between highand low-tide water levels. These areas may be often flooded and exposed with a diurnal or semi-diurnal frequency, and are associated to transitional or paralic areas from marine to terrestrial conditions. These settings can be estimated on the basis of several biological, sedimentologic and diagenetic features, which are sometimes observable in fossil, including ancient carbonate platforms [1]. In warm tropical and subtropical carbonate environments, intertidal areas are, in fact, characterized by the deposition of algal and microbial mats that influence the carbonate deposition through binding, trapping and by early diagenesis [1]. The intertidal bottoms of carbonate environments are subject to extreme changes in chemo-physical parameters (mainly temperature and salinity) and may also include the occurrence of saline pools (e.g. with ephemeral hypersaline circumstances) or brackish ponds.
In the Upper Cretaceous succession of the Apennine Carbonate Platform [2] a variety of rocks represented by laminated limestones, fenestral bindstone and calcimicrobialites associated with benthic foraminifera and microproblematica, commonly crops out and has been referred to an intertidal depositional setting [3,4]. The microfacies that represent this peculiar depositional environment comprise, among others, muddy low-energy wackestones and packstones with benthic foraminifera, often associated with mass occurrence of the alga Thaumatoporella and with the cyanobacteria Decastronema gr. kotoribarattoloi [5-8]. In the Apennine Carbonate Platform such facies can be found sandwiched within highly dolomitized levels representing the widespread of dry sabkha supratidal episodes or carbonate beach sequences $[9,10]$. A detailed facies characterization of these intertidal deposits, already proposed by Schlagintweit, et al. [4], is here enriched with some additional paleontological clues on the retrieved benthic foraminifera. Thus, aim of this contribution is to report and discuss the occurrence of these particular benthic 


\section{International Journal of Paleobiology \& Paleontology}

assemblages found within fossil Upper Cretaceous intertidal areas. The foraminifera here reported are often found as insitu component of the fossil living community, with no or very few traces of intraformational reworking. Additionally, a local accumulation of juveniles suggests that the area was used as a foraminiferal nursery, thus enabling the discussion of some interesting paleoecological insight.

\section{Geological Setting}

The Apennine Carbonate Platform was part of the extensive subtropical archipelago of shallow-water carbonates placed into the central Tethys ocean during the Mesozoic. It is one of the largest paleogeographic elements along the margin of Adria [11], together with other platforms such as the Panormide, Apulian, Adriatic and Gavrovo [2,12]. It was bordered to the west and to the north by the Ligurian Ocean, and separated from the Apulian Carbonate Platform to the east by the Lagonegro basin $[13,14]$. The stratigraphy of the Platform is represented by 4-5 km thick succession of Upper Triassic to Upper Cretaceous dolostones and limestones. The thickness of the Cretaceous succession is about 1000-1200 m [6].
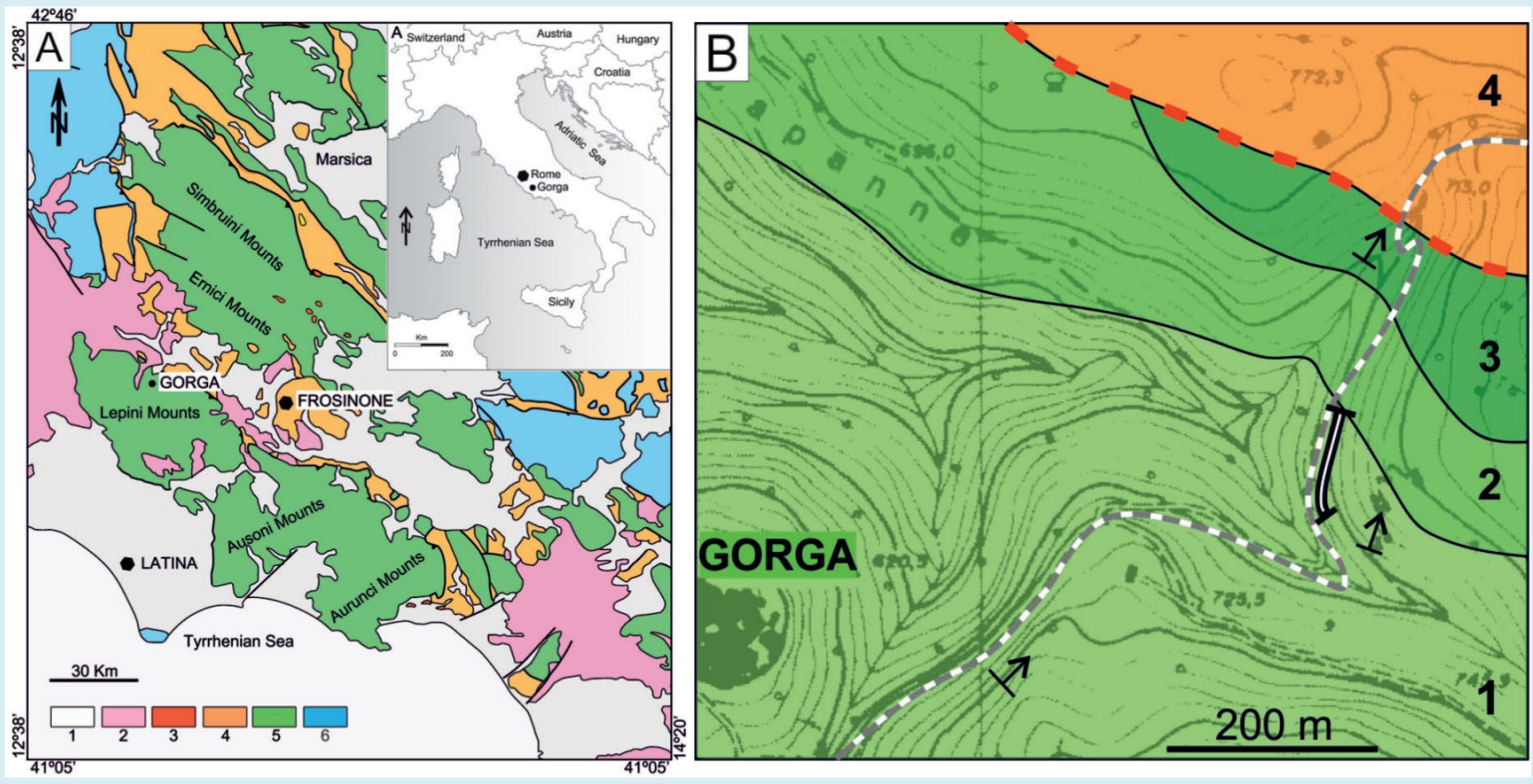

Figure 1: A: Geological map of the central Apennines modified after [2]. 1: Plio-Pleistocene marine and continental deposits; 2: Pleistocene volcanics; 3: Messinian clastic deposits and evaporites; 4: fore-deep siliciclastic deposits of undifferentiated age; 5: Meso-Cenozoic shallow-water limestones; 6: Meso-Cenozoic deep-water limestones.

B: Geological map of the study area around Gorga village; the dotted line refers to the dirty road that starts from Gorga and that cross eastward the Upper Cretaceous to Miocene carbonate succession. The continuous thick line refers to the trace of the sampled column (see the detailed column in Cruz-Abad et al. 2017) [20]. 1: Limestones and subordinated dolostones with rudist biostromes. The upper portion is characterized by peritidal facies with fenestrae. $R$. scarsellai and A. conica Discoribidae and ostracode Zones of Chiocchini, et al. [18]. Coniacian-lower Campanian. 2 and 3: laterally heteropic or superposed Limestones (2) and Calcarenites (3) with Orbitoides and Sivasella Discorbidae and Ostracodae-Ostracoda and Characeae Zones of Chiocchini, et al. [18]. Campanian-Maastrichtian 4: Echinids and bivalve calcarenite with Miogypsina globulina (bryozoa and lithotamnia Formation). Langhian.

This study investigates the Upper Cretaceous succession of the northern side of the Lepini mounts, which is a widespread carbonate mountain range $[15,16]$ at the westernmost portion of the central Apennines chain (Figure 1A). The studied succession crops out close to the village of Gorga (Figure 1B) and falls into the upper part of the hippuritids and radiolitids limestone Formation [15]. The biostratigraphy is mainly based on the vertical distribution of the benthic foraminifera found within these rocks and is referred to the upper part of the Accordiella conica and 


\section{International Journal of Paleobiology \& Paleontology}

Rotalispira scarsellai biozone and to the lower part of the discorbidae and ostracoda biozone [17], both Campanian in age $[18,19]$. The study succession is mainly composed by limestones alternated to dolostone levels and also represents the type locality of two benthic foraminifera named Rotalispira maxima Consorti, et al. and Lepinoconus chiocchinii Cruz, et al. $[16,20]$. The Cretaceous succession continues upward and is represented by a thick upper Campanian to Maastrichtian carbonate rock pack of brackish facies with characeae remains, laterally heteropic to calcilutitic grainstones with Orbitoides and Sivasella, in turn, unconformably covered, through an erosional surface, by the Miocene shallow-water carbonate deposits of the bryozoa and lithotamnia Formation (Figure 1B).

\section{Materials and Methods}

The study is based on a detailed analysis of 6 carbonate rocks samples prepared in thin section. The stratigraphic section from which the samples have been taken is about 100 $m$ thick and has been measured on the dirt track that begins at Gorga village and that leads to the east (base of the studied section: N 4139'19"-E 130.07'17"; top of the studied section: N 4139'25" -E1307'11", Figure 2A of Cruz-Abad, et al. [20]). This section falls in the lower part of the Rava Santa Maria section of Chiocchini and Mancinelli [17].

The succession is composed of limestones intercalated to dolomitic levels with birdseyes and desiccation structures. The fossil content consists of benthic foraminifera such as Accordiella conica Farinacci, Moncharmontia apenninica (De Castro), Scandonea mediterranea De Castro, Rotalispira scarsellai (Torre), Rotalispira maxima Consorti, Frijia \& Caus and Dicyclina schlumbergeri Munier-Chalmas. Lepinoconus chiocchinii Cruz-Abad et al. The demosponge Sarmentofascis zamparelliae Schlagintweit, Frijia \& Parente, Thaumatoporella, cyanobacteria like Decastronema kotori (Radiočić), nubeculariids and crustacean remains occurr mainly within the limestone facies.

\section{Results}

Three main microfacies have been observed (Figures $2 \& 3$ ). MF 1: Calcimicrobial foraminiferal bindstone (Figures 2A, 2E \& 2F; Figures 3A, 3B \& 3D). This microfacies type corresponds to the MFT-2 of Schlagintweit, et al. [4] and in part to the SMF 19 of Flügel [1]. In outcrop these limestones appear slightly laminated, where lamination is not continuous but often concentrated within some levels. Such a lamination is at $\mathrm{mm}$ - scale alternating wackestone and packstone textures to thin (less than $1 \mathrm{~mm}$ ) laminae of microbialitic origin that are often barely observable in thin section. Benthic foraminifera and calcimicrobes are always present, whereas Thaumatoporella algae accumulated only locally, that appears having a lenticular geometry. The cyanobacteria Decatronema and nubecularids foraminifera are very rare. Benthic foraminifera are represented by abundant thin walled miliolids, lamellar perforated forms like Rotalispira scarsellai (Torre) Rotalispira maxima, and Moncharmontia apenninica (De Castro), Scandonea mediterranea De Castro along with Accordiella conica Farinacci and Dicyclina schlumbergeri. Thaumatoporella occurs often flattened and crinkled. Thin remains of crab cuticles are also present. The foraminiferal shells appear frequently crushed and flattened, due to compaction and fast lithification rather than transport by reworking. The lamination is sometimes marked by the differences in the density of crushed Thaumatoporella. Foraminifera are selectively accumulated; in some areas porcelaneous forms dominate (Figures 2A \& 2E) whereas in other portions the assemblage is entirely characterized by lamellar perforated forms (Rotalispira) with few Accordiella conica, Moncharmontia apenninica and fragments of Dicyclina schlumbergeri. Where porcelaneous forms dominate (Figure 2E), the assemblage is totally represented by juvenile Scandonea individuals composed by two or three spiral whorls, along with small miliolids. The facies hosting concentration of Rotalispira is instead dominated by adult forms of $R$. maxima (Figure $2 \mathrm{~F}$ ) alternated to Thaumatoporella-rich layers. Siphovalvulinids foraminfiers sporadically appear in this microfacies (Figure 3).

MF 2: Nubecularids and Thaumatoporella fenestral wackestone (Figures 2B \& 2D). This microfacies is close to the MFT- 6 of Schlagintweit, et al. [4] and to the SMF 21 of Flügel [1]. The facies is a fenestral wackestone characterized by the occurrence of spherical Thaumatoporella along with nubecularids. In some cases, nubecularids dominate the assemblage (Figure 2D), whereas in other cases ostracods with articulated valvae occur. Other components comprise rare Decastronema and small miliolids.

MF 3: Decastronema wackestone (Figure 2C). This microfacies corresponds to the MFT- 5 of Schlagintweit, et al. [4]. It is characterized by the presence of abundant filament of the cyanobacteria Decastronema. Further components are represented by benthic foraminifera among them thin shelled miliolids abound. Few nubeculariids tests and few tiny bioclasts occur as well. The dominance of Decastronema filaments and the presence of a muddy matrix point to an intertidal depositional setting similar to recent Bahamian intertidal mudflat [7]. 

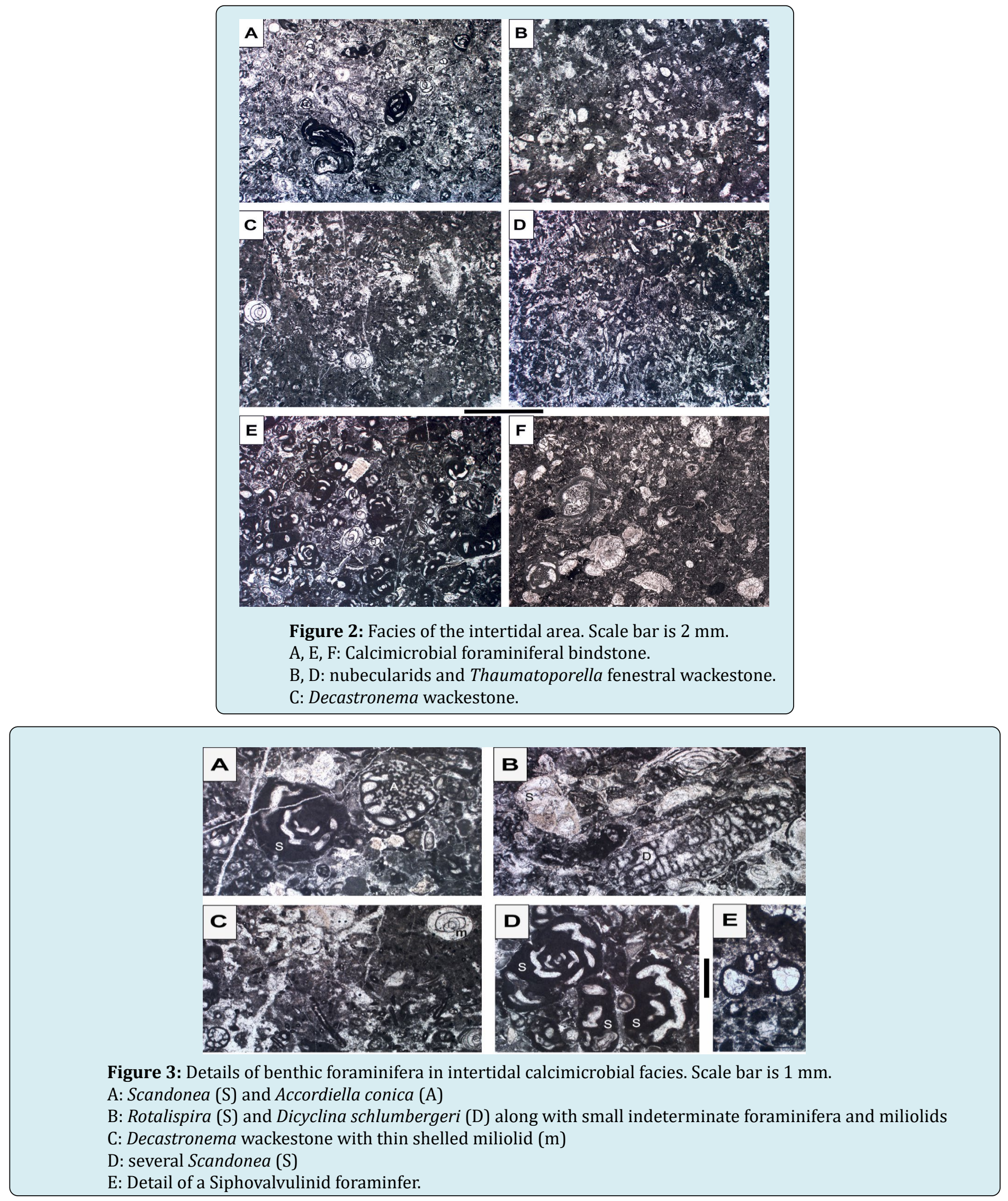


\section{International Journal of Paleobiology \& Paleontology}

\section{Discussion and Interpretation}

The alternating position of the study facies with highly dolomitized beds (that likely represent a sabkha plain) point to an intertidal zone. The occurrence of oligotypic benthic assemblages dominated by cyanobacteria, Thaumatoporella, nubeculariid foraminifera and thin shelled miliolids along with fenestrate sediments are comparable to other intertidal carbonate facies recognized elsewhere in the Upper Cretaceous $[4,5,8]$ or through further chronostratigraphic intervals $[21,1]$. In addition, interesting local assemblies of benthic foraminifera immersed in a calcimicrobial matrix or within a densely-packed Thaumatoporella paste occur.

Benthic foraminifera thriving in recent intertidal areas of carbonate platforms are associated with halophyte like mangrove and are subject to the effect of tides, high daily temperature, changes in freshwater runoff and hyperhaline conditions [22]. It has been also observed that, in recent environments, subtidal species temporarily colonize the intertidal flats, mostly in relation to some favorable environmental or seasonal conditions, leading to high diversity. In some cases, such as high latitude shelf, the intertidal belt is used by Ammonia for reproduction. In the Bahamian region the bottom of the intertidal areas is bound by algae and hosts porcelaneous (mostly miliolids and soritids) and subordinate epiphytic lamellar-perforate foraminifera. Sediment dwellers foraminifera are, in fact, common elsewhere under quite normal saline conditions [22], whereas Baculogypsina sphaerulata (Parker \& Jones) is instead one recent example of larger foraminifera thriving exclusively in intertidal carbonate areas [23].

Based on the information given by both recent examples and facies analysis, the occurrence of in-situ foraminifera observed in the MF 1 of this work furnish new palaeoecological information. The amount of juvenile Scandonea trapped between the microbial mats (Figure 2E) suggests ability to colonize intertidal areas during offspring release. This points that Scandonea preferred calm or low energy waters for reproduction, possibly remaining under extreme temperature and salinity circumstances, likely in small and isolated pools forming during the low tide. Both temperature and salinity were determining factors for choosing the nesting area, but not for a normal living setting as most times adult Scandonea, being particularly common within subtidal facies $[3,8]$, prefers thriving under normal marine conditions. The deposits hosting juveniles lack any traces of plants roots or obvious sedimentary structures allowing to reject the option of an accumulation driven by seagrass or bottom currents. The mild lamination observed sometimes in the outcrop is likely due to superposition of successive microbial films.
The Thaumatoporella calcimicrobialitic facies hosting Rotalispira maxima (Figure 2F) is rich in thin crab cuticles, or crustaceans remains [4], locally disposed in a laminated fabric. Individuals of Thaumatoporella and Rotalispira appear flattened and crushed suggesting compaction after deposition. The geometry of this deposit in the field is lenticular or, at least, circumscribed in a small restricted "pool" of few centimeter of extension. The characters thus point to an intertidal area with algal mat rich in organic matter crowded by herbivorous crustaceans. Foraminifers are embedded within the matrix and represented by un-decorticated adult individuals, including large Accordiella conica and few Moncharmontia apenninica. The Thaumatoporella calcimicrobialitic facies was crowded of living foraminifera at the time of deposition and most likely represented one of the feeding areas preferred by the genus Rotalispira. Being most of the ancient carbonate intertidal surface poor in nutrients by the lack of extensive run off or early cementation [1], local accumulation of organic matter including algae and microbial detritus would be attractive especially for deposit feeders. This behavior is expected in agglutinating forms found together with Rotalispira, like Accordiella conica or Moncharmontia. Although most of large K-strategists rotaliodeans host symbiontic algae to get energy [24,25], large Rotalispira may have preferred a shallow-infaunal deposit feeder habit as well, like in other cases described in the literature [26,27]. This also suggests that the species recovered throughout the intertidal area attained an opportunistic behavior (r-strategy) in order to exploit a limited amount of resources, and to extend their influence into a wider range of ecological niches [24]. This points out to an elevate tolerance of certain species to extreme environmental parameters that usually are established in intertidal areas during the low tide.

Exposure of the intertidal bottom results in surface sediment drying and an extreme condition of temperature and salinity along with higher light intensity [22]. This may lead an abrupt early diagenesis [1], with consequent exquisite preservation of the benthic assemblage at the time of the living community.

\section{Conclusion}

An interesting paleoecological insight on Upper Cretaceous benthic foraminifera from an intertidal area of the Apennine Carbonate Platform has been presented and discussed. Being the carbonate facies under investigation lithified in-situ at the time of the living community; the embedded benthic assemblage has been studied with high confidence. A rich accumulation of juvenile Scandonea suggests that small intertidal pools were used by certain porcelaneous foraminiferal species for offspring release and 


\section{International Journal of Paleobiology \& Paleontology}

as a nesting area. In other hand, several adult specimens of Rotalispira maxima are found crowling within a dense Thaumatoporella accumulation, most likely for feeding reasons. This study suggests that some Upper Cretaceous foraminiferal taxa were adapted to tolerate moments of extreme high temperature and salinity within the intertidal area, opening a view on the complex paleoecology of benthic life in ancient carbonate platforms.

\section{References}

1. Flügel E (2004) Microfacies of Carbonate Rocks: Analysis, Interpretation and Application. Springer, pp: 976.

2. Cosentino D, Cipollari P, Marsili P, Scrocca D (2010) Geology of the central Apennines: a regional review. Journal of the Virtual Explorer 36: 12.

3. Brandano M, Loche M (2014) The Coniacian-Campanian Latium-Abruzzi carbonate platform, an example of a facies mosaic. Facies 60: 489-500.

4. Schlagintweit F, Kołodziej B, Qorri A (2015) Foraminiferan-calcimicrobial benthic communities from Upper Cretaceous shallow-water carbonates of Albania (Kruja Zone). Cretaceous Research 56: 432-446.

5. Carannante G, Ruberti D, Sirna M (2000) Upper Cretaceous ramp limestones from the Sorrento Peninsula (southern Apennines, Italy): micro-and macrofossil associations and their significance in the depositional sequences. Sedimentary Geology 132(1-2): 89-123.

6. Frijia G, Parente M, Di Lucia M, Mutti M (2015) Carbon and Strontium isotope stratigraphy of the Late Cretaceous (Cenomanian-Campanian) shallow-water carbonates of southern Italy: chronostratigraphic calibration of larger foraminifera chronostratigraphic calibration of larger foraminifera biostratigraphy. Cretaceous Research 53: 110-139.

7. Golubic S, Radoičić R, Seong Joo L (2006) Decastronema kotori gen. nov., comb. nov.: a mat-forming cyanobacterium on Cretaceous carbonate platforms and its modern counterparts. Carnets de Géologie Notebooks on Geology.

8. Ruberti D, Toscano F (2002) Microstratigraphy and taphonomy of rudist shell concentrations in Upper Cretaceous limestones, Cilento area (central-southern Italy). Geobios, Memoire special 24: 228-240.

9. Carbone F, Catenacci V (1978) Facies analysis and relationship in upper Cretaceous carbonate beach sequences (Lepini mts., Latium). Geologica Romana 17: 191-231.
10. Mariotti G (1982) Alcune facies a rudiste dei Monti Carseolani: descrizione e correlazione dal bordo occidentale all'interno della Piattaforma LazialeAbruzzese. Geologica Romana 21: 885-902.

11. Channell JET, D’Argenio B, Horvath F (1979) Adria, the African Promontory, in Mesozoic Mediterranean palaeogeography. Earth-Science Reviews 15(3): 213292.

12. D’Argenio B (1970) Evoluzione geotettonica comparata tra alcune piattaforme carbonatiche del Mediterraneo Europeo ed Americane. Atti Accademia Pontaniana 20: $1-34$.

13. Mostardini F, Merlini S (1986) Appennino CentroMeridionale: sezioni geologiche e proposta di modello strutturale. Memorie della Società Geologica Italiana 35: 177-202.

14. Patacca E, Scandone P (2007) Geology of the Southern Apennines. In: Mazzotti A, Patacca E, Scandone P, (Eds.), CROP-04, Bollettino Società Geologica Italiana 7: 75-119.

15. Cardello GL, Consorti L, Palladino DM, Carminati E, Carlini M, et al. (2020) Tectonically controlled carbonateseated maar-diatreme volcanoes: The case of the Volsci Volcanic Field, central Italy. Journal of Geodynamics 139: 101763.

16. Consorti L, Frijia G, Caus E (2017) Rotaloidean foraminifera from the Upper Cretaceous carbonates of Central and Southern Italy and their chronostratigraphic age. Cretaceous Research 70: 226-243.

17. Chiocchini M, Mancinelli A (2001) Sivasella monolateralis Sirel and Gunduz, 1978 (Foraminiferida) in the Maastrichtian of Latium (Italy). Revue de Micropaléontologie 44(4): 267-277.

18. Chiocchini M, Pampaloni ML, Pichezzi RM (2012) Microfacies and microfossils of the Mesozoic carbonate successions of Latium and Abruzzi (Central Italy). Dipartimento Difesa del Suolo, Memorie per Servire alla Descrizione della Carta Geologica D'Italia, ISPRA 17: 269.

19. Chiocchini M, Chiocchini RA, Didaskalou P, Potetti M (2008) Microbiostratigrafia del Triassico superiore, Giurassico e Cretacico in facies di piattaforma carbonatica del Lazio centro-meridionale e Abruzzo: revision finale. In: Chiocchini M, (Ed.), Memorie Descrittive della Carta Geologica d' Italia, Torino 84: 5-170.

20. Cruz Abad E, Consorti L, Caus E (2017) Lepinoconus chiocchinii gen. n., sp. n., A conical Agglutinated Foraminifera from the Upper Cretaceous of Italy. Rivista 


\section{International Journal of Paleobiology \& Paleontology}

Italiana di Paleontologia e Stratigrafia 123(2): 347-354.

21. Barattolo F, Romano R (2005) Shallow carbonate platform bioevents during the Upper Triassic-Lower Jurassic: an evolutive interpretation. Bolletino della Società Geologica Italiana 124: 123-142.

22. Murray JW (2006) Ecology and Applications of Benthic Foraminifera. Cambridge University Press, pp: 426.

23. Hohenegger J, Yordanova E, Nakano Y, Tatzreiter F (1999) Habitats of larger foraminifera on the upper reef slope of Sesoko Island, Okinawa, Japan. Marine Micropaleontology 36(2-3): 109-168.

24. Hottinger L (2001) Learning from the past. In: Levi
Montalcini R, (Ed.), Frontiers of Life 4. Discovery and spoliation of the Biosphere. Academic Press, San Diego, pp: 449-477.

25. Hottinger L (2006) The depth-depending ornamentation of some lamellar-perforate foraminifera. Symbiosis 42 : 141-151.

26. Consorti L, Rashidi K (2018) A new evidence of passing the Maastichtian-Paleocene boundary by larger benthic foraminifers: The case of Elazigina from the Maastrichtian Tarbur Formation of Iran. Acta Palaeontologica Polonica 63(3): 595-605.

27. Hottinger L (2014) Paleogene Larger Rotaliid Foraminifera from the Western and Central Neotethys. Springer, pp: 191. 